\title{
Unusual nicotinoylation of 4-phenyl-5,7-dihydroxycoumarin
}

\author{
A.D. Sharapov *iD, R.F. Fatykhov, I.A. Khalymbadzha, A.P. Potapova, \\ P.A. Slepukhin, O.N. Chupakhin
}

Ural Federal University, 620002 Mira st., 19, Yekaterinburg, Russia

* Corresponding author: a.d.sharapov@urfu.ru

This short communication (letter) belongs to the MOSM2021 Special Issue.

(C) 2021, The Authors. This article is published in open access form under the terms and conditions of the Creative Commons Attribution (CC BY) license (http://creativecommons.org/licenses/by/4.0/).

\begin{abstract}
In the present work, we report a convenient synthesis of $5^{-}$and 7substituted-4-phenyl coumarins. In contrast to previous results obtained with 4-alkylcoumarins, nicotinoylation of 5,7-dihydroxy-4phenylcoumarin with nicotinoyl benzotriazole or nicotinoyl azide selectively provides $5-\mathrm{O}$ protected ester. The combination of the nicotinoylation reaction followed by tosylation-denicotinoylation yields 5-hydroxy-7-tosyloxy-coumarin derivative, which may be useful in the synthesis of inophyllum, a tetracyclic HIV reverse transcriptase inhibitor, as well as its analogues.
\end{abstract}

\section{Keywords}

5,7-dihydroxy-4phenylcoumarin

nicotinoylation

esterification

protecting group

inophyllum

Received: 18.11.2021

Revised: 21.12.2021

Accepted: 21.01.2022

Available online: 26.01.2022

\section{Introduction}

Asymmetrically O-substituted 5,7-dihydroxycoumarins attract attention as important building blocks for the synthesis of biologically active compounds. Compounds of this class are widespread both in nature, especially in plants in the form of mono- and diterpenes, and in synthetic compounds with important biological activity [1-4]. They have anti-cancer, antibacterial [5, 6], anti-HIV, antiinflammatory and others activities, For example, inophyllums (Fig. 1), a series of natural HIV reverse transcriptase inhibitors isolated from Calophyllum inophyllum tree [7], comprise asymmetrically O-substituted 5,7dihydroxycoumarin scaffold. Asymmetrically O-substituted 5,7-dihydroxycoumarins also can be used to prevent and treat Parkinson's disease, brain lesions, and dementia [8].<smiles>C[C@H]1Oc2c3c(c4c(-c5ccccc5)cc(=O)oc4c2[C@H](O)[C@@H](C)[C@@H]1O)OC(C)(C)C=C3</smiles>

Inophyllums A,B,D,P<smiles>CC1Oc2c3c(c4c(-c5ccccc5)cc(=O)oc4c2O1)C=CC(C)(C)[C@@H](C)C3=O</smiles>

Inophyllums $\mathrm{C}$ and $\mathrm{E}$
Fig. 1 Structure of naturally occurring inophyllums
We have previously demonstrated that nicotinoylation of 5,7-dihydroxy-4-alkylcoumarins is a convenient method for the synthesis of both 5- and 7-hydroxy-substituted coumarins $[9,10]$. In this case, the nicotinoylation reaction proceeds at the sterically less hindered hydroxy group at position $\mathrm{C}_{7}$ of coumarin system (Scheme 1). Subsequent modification of free 5-OH hydroxy group with a protective group orthogonal to nicotinoyl (tosyl or di(tertbutyl)phenylsilyl) and removal of the nicotinoyl moiety under acidic conditions allows the synthesis of complementary 5-OH protected coumarins [9].

In the presented work, we expand this methodology of selective nicotinoylation to 4-aryl-5,7-dihydroxycoumarins.

\section{Experimental}

Unless otherwise noted, all commercially available compounds were used without further purification.

1-Nicotinoyl benzotriazole [10], nicotinoyl azide [11], and 5,7-dihydroxy-4-phenylcoumarin [12] were prepared in accordance with published procedures.

${ }^{1} \mathrm{H}$ and ${ }^{13} \mathrm{C}$ NMR spectra were recorded at ambient temperature on a Bruker Avance II $400 \mathrm{MHz}$ spectrometer at 400 and $100 \mathrm{MHz}$, respectively, in DMSO-d 6 or DMSO$\mathrm{d}_{6}: \mathrm{CCl}_{4}$ mixture as a solvent.

Chemical shifts $(\delta)$ are given in ppm relative to the DMSO residual peak (2.50 ppm) as an internal standard. 

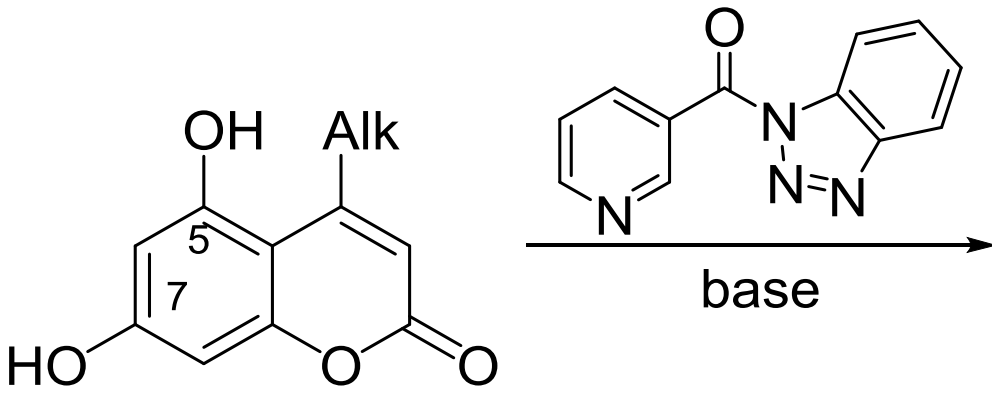

base

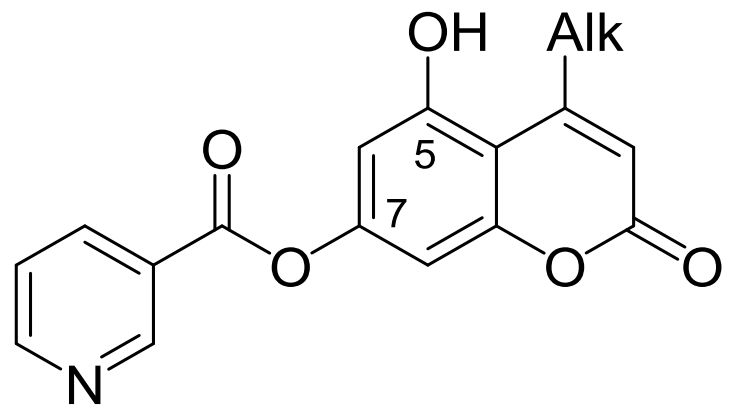

Scheme 1 Nicotinoylation of 5,7-dihydroxy-4-alkylcoumarin

The X-ray diffraction data for compound $\mathbf{2}$ were obtained from a $0.30 \times 0.25 \times 0.20 \mathrm{~mm}$ single crystal (colorless prism) at 295(2) $\mathrm{K}$ on an Xcalibur $\mathrm{E}$ diffractometer with a CCD detector $(\mathrm{Cu} \mathrm{K} \alpha$ radiation, $\lambda=154.184 \mathrm{pm}$, graphite monochromator).

\subsection{Procedure for synthesis of 2,3 , and 4 compounds}

\subsubsection{7-Hydroxy-2-oxo-4-phenyl-2 $H$-chromen-5-yl nico- tinate 2}

5,7-Dihydroxy-4-phenylcoumarin $\quad(2.540 \mathrm{~g}, \quad 10.0 \mathrm{mmol})$, triethylamine (1.111 $\mathrm{g}, 11.0 \mathrm{mmol})$, and nicotinoyl azide or nicotinoylbenzotriazole (10.0 $\mathrm{mmol})$ were dissolved in acetone $(30 \mathrm{ml})$. The mixture was allowed to stand for 12 hours and the precipitate formed was filtered. Yield $1.860 \mathrm{~g}(52 \%)$.

${ }^{1} \mathrm{H}$ NMR (400 MHz, DMSO-d $\left.6+\mathrm{CCl}_{4}\right) \delta 10.83,8.67(d$, $J=4.9 \mathrm{~Hz}, 1 \mathrm{H}), 8.57(s, 1 \mathrm{H}), 7.78(d, J=8.0 \mathrm{~Hz}, 1 \mathrm{H})$, $7.33(d d, J=8.0 \mathrm{~Hz}, J=4.9 \mathrm{~Hz}, 1 \mathrm{H}), 7.22-7.22(m, 2 \mathrm{H})$, 7.04-7.08 $(m, 2 \mathrm{H}), 6.77-6.8 \mathrm{o}(m, 2 \mathrm{H}), 6.54(s, 1 \mathrm{H})$, $5.88(s, 1 \mathrm{H}) .{ }^{13} \mathrm{C}$ NMR (101 MHz, DMSO) $\delta$ 162.62, 161.26, $158.68,156.03,153.50,153.13,149.99,147.91,137.59$, $136.73,127.79,127.45,126.72,123.53,122.81,113.28$, 108.29, 104.88, 101.44. Anal. Calcd. for $\mathrm{C}_{21} \mathrm{H}_{13} \mathrm{NO}_{5}$ : C, 70.19; H, 3.65; N, 3.90. Found: C, 70.01; H, 3,75; N, 3.79.

An empirical correction for absorption $\left(\mu=0.875 \mathrm{~mm}^{-1}\right)$ was applied. Triclinic crystal system, space group $P$-1; unit cell parameters: $a=9.240(7), b=9.946(8), c=10.604(10) \AA$; $\alpha=83.33(7)^{\circ} ; \beta=69.90(8)^{\circ} ; \gamma=63.77(8)^{\circ} ; V=820.2(12) \AA^{3}$; $Z=2$. Total of 8848 reflection intensities were measured in the range $4.44<\theta<65.28$, including 2705 independent reflections ( $R_{\text {int }}=0.0517$ ), and 1795 reflections with $I>2 \sigma(I)$; completeness $96.2 \%$ for $\theta=65.28^{\circ}$. The structure was solved by the direct method and was refined by the least-squares method using SHELXTL package [13]. All hydrogen atoms were placed in directly calculated positions which were refined according to the riding model in isotropic approximation. Goodness of fit $S=1.005$; final divergence factors: $R_{1}=0.0569, W R_{2}=0.0942$ for reflections with $I>2 \sigma(I) ; R_{1}=0.0419, w R_{2}=0.0971$ for all independent reflections. The X-ray diffraction data for compound $\mathbf{2}$ were deposited to the Cambridge Crystallographic Data Centre (CCDC entry no. 2129495) [14].

\subsubsection{2-Oxo-4-phenyl-7-(tosyloxy)-2 $H$-chromen-5-yl nico- tinate 3}

To a suspension of 7-hydroxy-2-oxo-4-phenyl-2 $\mathrm{H}$ chromen-5-yl nicotinate 2 (1795 $\mathrm{mg}, 5.0 \mathrm{mmol}$ ) in DCM (35 ml) was added dimethylaminopyridine (2440 mg, $10.0 \mathrm{mmol}$ ) and tosyl chloride (1194 $\mathrm{mg}, 6.25 \mathrm{mmol}$ ). The mixture was stirred for $30 \mathrm{~min}$., washed with water $(3 \times 50 \mathrm{ml})$, dried and evaporated to yield 3 (1.638 g, 65\%) as a white solid.

${ }^{1} \mathrm{H}$ NMR (400 MHz, DMSO-d6) $\delta 8.74(d d, J=4.9 \mathrm{~Hz}$, $J=1.7 \mathrm{~Hz}, 1 \mathrm{H}), 8.57(d, J=2.5 \mathrm{~Hz}, 1 \mathrm{H}), 7.87(d, J=8.2 \mathrm{~Hz}$, $2 \mathrm{H}), 7.8 \mathrm{o}(d d, J=8.0 \mathrm{~Hz}, J=2.0 \mathrm{~Hz}, 1 \mathrm{H}), 7.52(d, J=8.2$ $\mathrm{Hz}, 2 \mathrm{H}), 7.41(d d, J=8.0 \mathrm{~Hz}, J=4.8 \mathrm{~Hz}, 1 \mathrm{H}), 7.21-7.28(\mathrm{~m}$, $4 \mathrm{H}), 7.07-7.11(m, 2 \mathrm{H}), 6.82(d d, J=7.51 \mathrm{~Hz}, 1 \mathrm{H}), 6.27(s$, $1 \mathrm{H}), 2.43(s, 3 \mathrm{H}) .{ }^{13} \mathrm{C}$ NMR (101 MHz, DMSO) $\delta 162.64$, $158.09,154.58,153.99,152.01,150.35,150.03,147.70$, $146.40,137.04,136.77,130.90,130.46,128.31,128.01$, $127.90,126.98,123.33,123.20,117.90,114.45,112.04$, 108.98, 21.18. Anal. Calcd. for $\mathrm{C}_{28} \mathrm{H}_{19} \mathrm{NO}_{7} \mathrm{~S}$ : Elemental analysis: C, 65.49; H, 3.73; N, 2.73. Found: C, 65.35; H, 3,58; N, 2.93 .

\subsubsection{5-Hydroxy-2-oxo-4-phenyl-2 $H$-chromen-7-yl 4- methylbenzenesulfonate 4}

A suspension of 2-oxo-4-phenyl-7-(tosyloxy)-2 $\mathrm{H}$-chromen5-yl nicotinate $3(1008 \mathrm{mg}, 2.0 \mathrm{mmol})$ was stirred in a mixture of ethanol $(20 \mathrm{ml})$ and $30 \%$ hydrochloric acid $(12 \mathrm{ml})$ at $80{ }^{\circ} \mathrm{C}$ for 4 hours. The mixture was cooled and precipitate was filtered off. Yield $710 \mathrm{mg}, 87 \%$.

${ }^{1} \mathrm{H}$ NMR (400 MHz, DMSO-d6) $\delta 10.77(s, 1 \mathrm{H}), 7.82(d$, $J=8.0 \mathrm{~Hz}, 2 \mathrm{H}), 7.50(d, J=8.0 \mathrm{~Hz}, 2 \mathrm{H}), 7.32-7.38(\mathrm{~m}$, $5 \mathrm{H}), 6.57(d, J=2.4 \mathrm{~Hz}, 1 \mathrm{H}), 6.43(d, J=2.4 \mathrm{~Hz}, 1 \mathrm{H})$, $6.04(s, 1 \mathrm{H}), 2.43(s, 3 \mathrm{H}) .{ }^{13} \mathrm{C}$ NMR (101 MHz, DMSO-d 6$) \delta$ $158.89,156.90,155.37,154.71,151.29,146.15,138.63,131.20$, $130.38,128.22$, 128.06, 127.40, 127.32, 114.70, 106.42, 104.82, 101.03, 21.19. Anal. Calcd. for $\mathrm{C}_{22} \mathrm{H}_{16} \mathrm{O}_{6} \mathrm{~S}$ : Elemental analysis: C, 64.7O; H, 3.95. Found: C, 64.57; H, 4.02; N, 3.00.

\section{Results and discussion}

We found that nicotinoylation of 5,7-dihydroxy-4phenylcoumarin 1 with nicotinoylbenzotriazole ( $\mathrm{X}=$ benzotriazolyl) or nicotinic acid azide $\left(X=N_{3}\right)$ leads to unexpected 5-nicotinoyloxy-4-phenylcoumarin 2 (Scheme 2). 
<smiles>O=c1cc(-c2ccccc2)c2c(O)cc(O)cc2o1</smiles>

1

Scheme 2 Nicotinoylation of 5,7-dihydroxy-4-phenylcoumarin

The reaction takes place at most sterically hindered $5-\mathrm{OH}$ position as confirmed by X-ray structural analysis of compound (Fig. 2). One may assume that the selectivity of this reaction is associated with non-covalent interactions in the transition state, such as $\pi-\pi$ stacking between the pyridyl ring of nicotinoyl derivatives and the phenyl ring of coumarin.

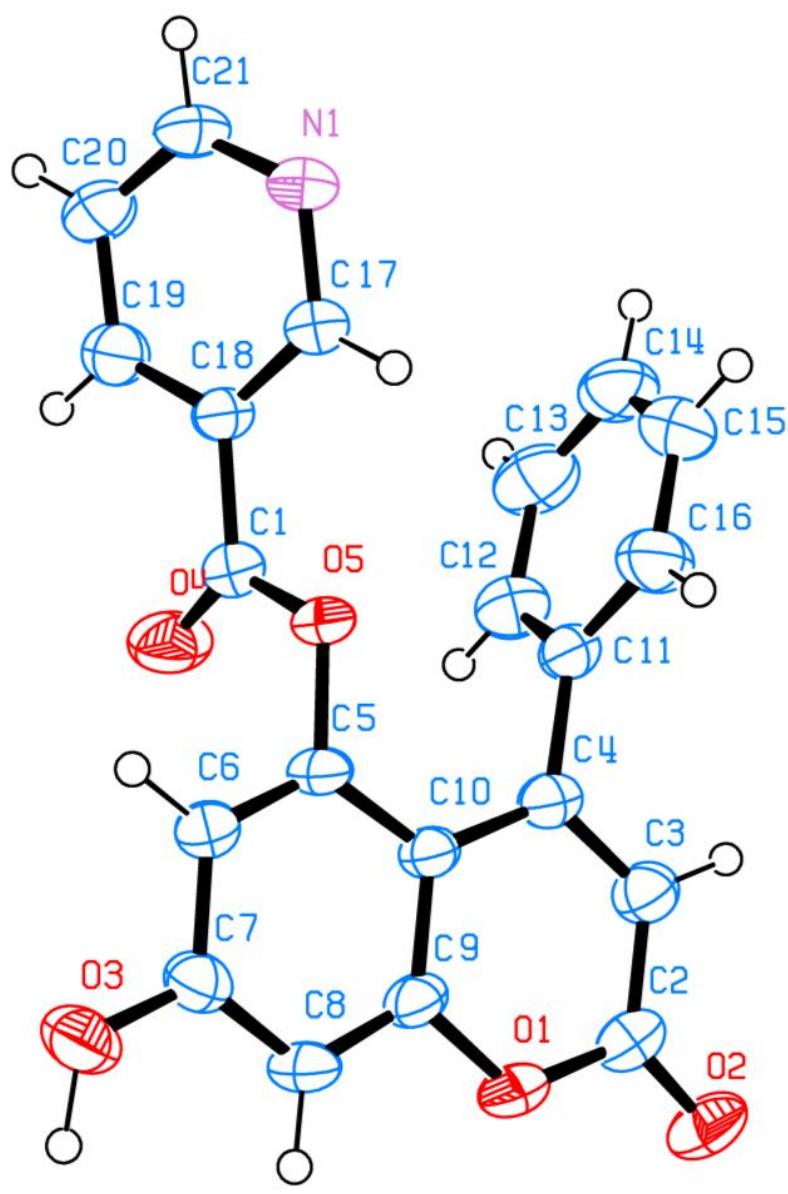<smiles>O=C(Oc1cc(O)cc2oc(=O)cc(-c3ccccc3)c12)c1cccnc1</smiles>

2

To obtain 5-hydroxy-7-O-subsituted derivatives of coumarin 1 , we carried out the exchange of hydroxy protective groups. Thus, tosylation of $\mathbf{2}$ with p-toluenesulfonyl chloride followed by denicotinoylation of 3 in an acidic media provides 7-protected tosyloxy derivative $\mathbf{4}$ (Scheme 3). Compound 4 may be further converted to inophyllum or inophillum analogues using adapted procedures [9].

\section{Conclusions}

Thus, we presented a convenient synthesis of $5^{-}$and $7^{-}$ substituted 4-phenyl coumarins. It was demonstrated that 4phenyl-5,7-dihydroxycoumarins, unlike 4-alkyl compounds, react with nicotinoylazide with the involvement of the 5hydroxy group in the reaction. The structure of the nicotinoyl derivative was proved by X-ray diffraction analysis. Combination of the nicotinoylation with tosylationdenicotinoylation allows one to obtain 7-hydroxy protected 5,7-dihydroxycoumarins.

\section{Acknowledgments}

This work is financially supported by Russian Science Foundation (Ref No. 21-13-00382).

\section{Declaration of competing interests}

The authors declare that they have no known competing financial interests or personal relationships that could have appeared to influence the work reported in this paper.

Fig. 2 The X-ray structure (CCDC 2129495) of compound 2<smiles>O=c1cc(-c2ccccc2)c2c(O[Na])cc(O)cc2o1</smiles>

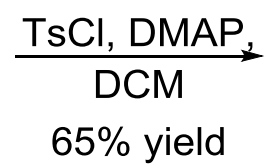
2<smiles>N#[N+]Oc1cc(OC(F)(F)F)cc2oc(=O)cc(-c3ccccc3)c12</smiles>

3

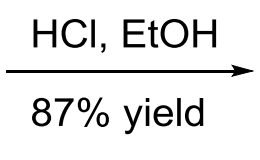<smiles></smiles>

4

Scheme 3 Protective groups exchange in compound $\mathbf{2}$ 


\section{References}

1. Fatykhov RF, Chupakhin ON, Inyutina AK, Khalymbadzha IA. Synthetic Approaches to Unsymmetrically Substituted 5,7Dihydroxycoumarins. Synthesis. 2020;52:66o-672. doi:10.1055/s-0039-1690780

2. Murray RDH. The naturally occurring coumarins. Fortschr Chem Org Naturst. 2002;83:1-619. doi:10.1007/978-3-7091-6172-2_1

3. Srikrishna D, Godugu C, Dubey PK. A Review on Pharmacological Properties of Coumarins. Mini Rev Med Chem. 2018;18:113-141. doi:10.2174/1389557516666160801094919

4. Stefanachi A, Leonetti F, Pisani L, Catto M, Carotti A. Coumarin: A Natural, Privileged and Versatile Scaffold for Bioactive Compounds. Molecules 2018;23:250. doi:10.3390/molecules23020250

5. Sakunpak A, Matsunami K, Otsuka H, Panichayupakaranant P. Isolation of new monoterpene coumarins from Micromelum minutum leaves and their cytotoxic activity against Leishmania major and cancer cells. Food Chem. 2013;139:458-463. doi:10.1016/j.foodchem.2013.01.031

6. Kaur M, Kohli S, Sandhu S, Bansal Y. Coumarin: a promising scaffold for anticancer agents. Anti-Cancer Agents Med Chem. 2015;15:1032-1048. doi:10.2174/1871520615666150101125503

7. Patil AD, Freyer AJ, Eggleston DS, Haltiwanger RC, Bean MF, Taylor PB, Caranfa MJ, Breen AL, Bartus HR. The inophyllums, novel inhibitors of HIV-1 reverse transcriptase isolated from the Malaysian tree, Calophyllum inophyllum Linn. J Med Chem. 1993;36:4131-1138. doi:10.1021/jmooo78a001
8. Ji HJ, Wang DM, Hu JF, Sun MN, Li G, Li ZP, Wu DH, Liu G, Chen NH. IMM-Hoo4, a novel coumarin derivative, protects against oxygen-and glucose-deprivation/restoration-induced apoptosis in PC12 cells. Eur J Pharmacol. 2014;723:259-266. doi:10.1016/j.ejphar.2013.11.023

9. Inyutina AK, Fatykhov RF, Khalymbadzha IA, Sharapov AD, Bobkina MV, Chupakhin ON. New approach to the synthesis of biologically active derivatives of pyranocoumarins. AIP Conf Proc. 2019;2063:040019. doi:10.1063/1.5087351

10. Fatykhov RF, Khalymbadzha IA, Chupakhin ON, Charushin VN, Inyutina AK, Slepukhin PA, Kartsev VG. 1Nicotinoylbenzotriazole: A Convenient Tool for Site-Selective Protection of 5,7-Dihydroxycoumarins. Synthesis. 2019;51:3617-3624. doi:10.1055/s-0039-1690104

11. Adkinson DK, Magri DC, Pitters JL, Griffiths K, Norton PR, Workentin MS. Photolysis and Thermolysis of Pyridyl Carbonyl Azide Monolayers on Single-Crystal Platinum. Photochem Photobiol. 2013;89(5):1020-1028. doi:10.1111/php.12086

12. Iinuma M, Tanaka T, Hamada K, Mizuno M, Asai F. Flavonoids Syntheses. VI. Synthesis and Spectral Properties of 4Arylcoumarins (Neoflavones). Chem Pharm Bull. 1987;35:3909-3913. doi:10.1248/cpb.35.3909

13. Sheldrick GM, A short history of SHELX. Acta Crystallogr Sect A. 2008;64:112-122. doi:10.1107/S0108767307043930

14. The Cambridge Crystallographic Data Centre (CCDC). Available online: http://www.ccdc.cam.ac.uk 